Archives of Agriculture and Environmental Science

\title{
Identification of terrestrial gastropods species in Sohag Governorate, Egypt
}

\author{
Abd El-Aleem Saad Soliman Desoky \\ Department of Plant protection (Agriculture Zoology), Faculty of Agriculture, Sohag University, EGYPT \\ E-mail: abdelalem2011@yahoo.com
}

\section{ARTICLE HISTORY}

Received: 15 January 2018

Revised received: 10 February 2018

Accepted: 21 February 2018

\section{Keywords}

Egypt

Eobania vermiculata

Land snails

Monacha obstracta

Terrestrial gastropods

\section{ABSTRACT}

The study aims to identify of terrestrial gastropods species in Sohag Governorate during the year 2016 and 2017. The present study was carried out for survey and identification for random land snail in 11 districts, i.e. (Tema, Tahta, Gehyena, El-Maragha, Saqultah, Sohag, Akhmim, El-Monshah, Gerga, El-Balyana, and Dar El-Salam) at Sohag Governorate, Egypt. Samples were collected from 5 different locations in each district during 2016-2017 seasons. The monthly samples were taken from winter and summer crops (areas were cultivated with the field crops such as wheat, Egyptian clover, and vegetables crops. The results showed that found two species of land snails, Monacha obstracta (Montagu) and Eobania vermiculata (Muller). It was also observed that the occurrence of the spread of land snails was increased from the previous periods. The results further indicated that land snails were recorded in Sohag for a second time more widespread and may be that this pest moved to these governorates with transportation, passengers from places spread these new places and happened to her adaptation and after have transferred from infestation regions so, have adapted under weather factors of new region also, several factors e.g., the presence of more preferable food, shelter, intra-specific competition, fecundity increasing, several hosts or habitat in the new ecosystems. Therefore, this study gives an interesting indication of the development of a plan in effective strategy for land snail's management program in agro ecosystems in Upper Egypt.

(C)2018 Agriculture and Environmental Science Academy

Citation of this article: Desoky, A.S.S. (2018). Identification of terrestrial gastropods species in Sohag Governorate, Egypt. Archives of Agriculture and Environmental Science, 3(1): 45-48 DOI: 10.26832/24566632.2018.030105

\section{INTRODUCTION}

In Egypt, terrestrial snails and slugs represent important economic pests and they are prevalent in many Governorates infesting and causing severe damage to many economic crops i.e. vegetable crops, ornamental plants, orchard trees and field crops (El-Okda, 1980; Azzam, 1998; Desoky et al., 2015). Land snails cause heavy damage was manifested in chewing soft vegetative growing, the flowers and fruits, also eating seeds, roots and tubers after the sowing or during repining. (El-Okda, 1980; Imevore and Ajayi, 1993; Ismail et al., 2003; Ramzy, 2009). In addition, the movement of snails causes an unwanted smell which avoids men and even animals from feeding on these polluted plants (Sallam et al., 2009). Furthermore, some gastropods work as intermediate hosts for many parasitic worms infesting man and his domestic animals (Barker, 2001).

In Egypt, the land snails dispersing in northern Governorate,
Alexandria, El-Beheira, Kafr El-Shikh, and Domietta (Kassab and Daoud, 1964; El-Okda, 1980; Hashem et al., 1993; and Eshra, 2103 ) At the present time these snails distribute in Ismaellia, Sharkia, Monofia, Gharbia, Minia, and Assiut Governorates (ElDeeb et al., 2004; and Shoieb, 2008). Nine terrestrial snail species in Upper Egypt region has been identified by Assiut Governorate. All the species recorded belong to order: Pulmonata from eight families (Ramzy, 2009). Keeping in view the significance of gastropods in agricultural fields, the present study was undertaken for the identification of terrestrial snail species in Sohag Governorate, Egypt.

\section{MATERIALS AND METHODS}

The present study was carried out for survey and identification for random land snail in 11 districts, i.e. (Tema, Tahta, Gehyena, El-Maragha, Saqultah, Sohag, Akhmim, El-Monshah, Gerga, 
El-Balyana, and Dar El-Salam) at Sohag Governorate, Egypt. Samples were collected from 5 different locations in each district during 2016/2017 season. Monthly samples were taken from winter and summer crops (areas were cultivated with the field crops such as wheat, Egyptian clover, and vegetables crops.

The other, was cultivated with fruit and ornamental trees). Snails collected from each sample were drowned overnight in water to facilities extension of the foot from the shell in any snails collected live. Snails were considered to have been alive at collection when the foot extended from the shell during drowning. Snails from each host plant in each surveyed areas were transferred in muslin cloth bags to the laboratory and identified according to the keys given by Smith and Kershaw (1979) and Godan (1983). After 24 hours, the water was decanted and replaced with $70 \%$ ethanol for preservation. The snails with complete soft parts were identified. To morphology study of the collected shell of the snail species respectively, shell was prudently washed and the visceral mass was removed according to the method of Frandsen (1983). After that, the shell of each species was photo graphed. The following references, beside others cited in the text, were used in the documentation of the collected snails: Pilsbry (1948); Horst (1958); Cameron and Radfern (1976); Godan (1983); Dindal (1990); Neubert (1998); Ibrahim et al. (1999); Barker (2001); Genena (2003); Yildirim (2004) Ramzy (2009).

\section{RESULTS AND DISCUSSION}

Mollusca are the second largest phylum of the animal kingdom, forming a major part of the world fauna. The gastropoda is the only class of mollusks which have successfully invaded land. They are one of the most diverse groups of animals, both in shape and habit. Amongst the gastropods, land snails (sub class: Pulmonata) are one of the maximum frequent with almost 35.000 described species of the world.

Data in Table (1), the terrestrial snail species were identified in many different sites at Sohag Governorate, during the study period 2016-2017 seasons. Through the table, the results showed the identification of two lands and their distribution was as follows Monacha obstracta was recorded in the following areas (Tema, Tahta, Gerga, El-Balyana and DarEl-Salam districts). While the Eobania vermiculata was recorded in the following areas (Tema, Tahta, Saqultah, El-Maragha, Akhmim (Sohag, districts).

In the past years were land snails distributed in North Delta, where suitable climatic conditions (temperature-humidity-plant cover) and with climate change began to distribute in the governorates of southern Egypt recorded an in (Giza, BeniSuef, Minia, Assiut). In this study, land snails were recorded in Sohag for a second time more widespread and may be that this pest moved to these governorates with transportation, passengers from places spread these new places and happened to her adaptation and after have transferred from infestation regions so, have adapted under weather factors of new region also, several factors e.g., the presence of more preferable food, shelter, intraspecific competition, fecundity increasing, several hosts or habitat in the new ecosystems. This finding is in agreement with El-Okda (1979) recorded individuals of E. vermiculata at Shatby and SediBechr districts, Alexanderia. While, M. obstructa was recorded in Behera (El-Deeb et al., 1999). Metwally et al. (2002) recorded six terrestrial snails include M. cartusiana, E. vermiculata, C. acuta, O. alliarus; the slugs, L. flavus and Deroceras reticulatum on different crops at 23 localities representing 10 districts at Monofia and Gharbia Governorates.

E. vermiculata and M. obstructa were recorded in the coastal area of the Nile Delta by El-Deeb et al. (1996 )and (2003) measured altered earthly snails on the field crops, vegetables, ornamental plants and the orchards at different Governorates of Egypt. Results showed that M. cartusiana, E. vermiculata, C. acuta, Cepaea nemoralis, Oxychilus aliavus and Helicella sp. were recorded on different host plants in Demietta Governorate while $M$. cartusiana, E. vermiculata, C. acuta, C. nemoralisand S. putris were found in Dakahlia Governorate. However, E. vermiculata, C. nemoralisand S. putris were common species in Kafr El-Sheik Governorate. While, M. obstructa was recorded in Kafr El-Sheikh (Gabr et al., 2006) and in Ismailia Governorate (Shoieb, 2008).

Ramzy (2009) surveyed nine land snail species in Assiut Governorate namely, E. vermiculata, M. obstructa, O. elegans, Vallonia pulechella, T. pisana, Vitrea pygmaea, Helicodiscus singleyanus inermis, Pupoides coenopictus and Cecilioides acicula. The first three species are accessory species while the accidental species include the other six snail species. In addition, O. elegans, V. pygmaea, $P$. coenopictus and C. acicula were recorded for the first time in Egypt. Abo-El-Naser (2013) found that four terrestrial snails include three land snails and slugs were found in the main investigated sites in Assiut Governorate. The three land snail

Table 1. Survey of land snails collected from different districts in Sohag Governorate, Egypt, during 2016-2017.

\begin{tabular}{|c|c|c|c|c|}
\hline S.N. & Crops & Sites (districts) & Monacha obstracta & Eobania vermiculata \\
\hline 1 & & Tema & + & + \\
\hline 2 & & Tahta & + & + \\
\hline 3 & & Gehyena & - & - \\
\hline 4 & Egyptian clover & Saqultah & - & + \\
\hline 5 & Wheat & El-Maragha & - & + \\
\hline 6 & Orchards & Akhmim & - & + \\
\hline 7 & Ornamental trees & Sohag & - & + \\
\hline 8 & Vegetables & El-Monshah & - & - \\
\hline 9 & etc...., & Gerga & + & - \\
\hline 10 & & El-Balyana & + & - \\
\hline 11 & & DarEl-Salam & + & - \\
\hline
\end{tabular}

+ Found; - Unfound 
species are Monacha obstructa (Montagu); Eobania vermiculata (Muller) and Oxyloma elegans (Risso) while a slug is Limax flavus (Muller). All terrestrial snails, M. obstructa, E. vermiculata, O. elegans and L. flavus were recorded in the Exp. Farm, Fac. Agric., Assiut Univ., while M. obstructa was recorded only in El-Wasta in Assiut Governorate, during the investigation period. L. flavus was recorded for the first time in Assiut Governorate. These results can be used for future studies as follows: future work plan in an effective strategy for the implementation of snail's management programs at varying environmental regulations in Egypt. Desoky et al. (2015) the results showed that found first record and identified of two land snail species in Sohag Governorate. They are as follows Monacha obstracta and Eobania vermiculata.

\section{Conclusion}

The present study concluded the occurrence of two species of land snails, Monacha obstracta (Montagu) and Eobania vermiculata (Muller) in the Sohag Governorate, Egypt. It was also noted that the spread of land snails was increased from previous periods. The results also indicated that land snails were recorded in Sohag for a second time more widespread and may be that this pest moved to these governorates with transportation, passengers from places spread these new places and happened to her adaptation and after have transferred from infestation regions so, have adapted under weather factors of new region also, several factors e.g., the presence of more preferable food, shelter, intra-specific competition, fecundity increasing, several hosts or habitat in the new ecosystems. Therefore, the present investigation provides an interesting development plan for the effective strategy for land snail's management program in agro ecosystems in the Upper region of Egypt.

Open Access: This is open access article distributed under the terms of the Creative Commons Attribution License, which permits unrestricted use, distribution, and reproduction in any medium, provided the original author(s) and the source are credited.

\section{REFERENCES}

Abo-El-Naser, H.A.K. (2013). Ecological and biological control studies on some terrestrial snails and their associated arthropods in Assiut Governorate. M.Sc. Thesis, Faculty of Agriculture, Assiut University, Egypt, pp.108.

Azzam, K.M. (1998). First record of the snail parasitic nematode Rhabditis sp. isolated from Egyptian terrestrial snails and its compability to infect other pests. Egyptian Journal of Biological Pest control, 8: 27-29.

Barker, G.M. (2001).The biology of terrestrial Molluscs. CABI publishing, New Yourk, USA, pp.558.

Cameron, R.A.D and Redfern, M. (1976). British land snails (Mollusca: Gastropoda), Key and notes for the identification of the species. Linnean Society of Landon, pp.63.
Desoky, A.S.S., Sallam, A.A. and Abd El-Rahman, T.M.M. (2015). First record of two species from land snails, Monacha obstracta and Eobania vermiculata in Sohag Governorate, Egypt. Direct Research Journal of Agriculture and Food Science, 3 (11): 206-210.

Dindal, D.L. (1990). Soil biology guide. A Wiley, Inter science Publication, New-York, pp.1349.

El-Deeb, H.I., Abdel-Halim, A., Koutb, I., Khidr, F.K. and Edress, N.M. (2004). Studying some ecological aspects associated with the prevalent land snails at Kafr El-Sheikh governorate. Journal of Agricultural Science, Mansoura University, 29: 2847-2853.

El-Deeb, H.I., El-Ghamry, E.M., El-Hwashyand, N. and Essa, N. (1996). Relative abundance of some land snails in certain governorate of Egypt. Journal of Agricultural Science, Mansoura University, 21(8): 2977-2983.

El-Deeb, H.I., Wilson, M. and Eshara, E.H. (1999). Ecological studies on certain land snails infest some Economic crops at Beheira Governorate, Egypt. Proceedings of $2^{\text {nd }}$ Intentional Conference Pest Control, Mansoura, Egypt, 19-28.

El-Deeb, H.I., Zidan, Z.H., Fouad, M.M. and Asran, F.D. (2003). Survey of terrestrial snails and their malacophagous insects at three Governorates in Egypt. Egyptian Journal of Applied Science, 18: 355-361.

El-Okda, M.K. (1980). Land snails of economic importance on vegetable at Alexandrina\& neighboring region. Agricultural Research Review, 58: 79-85.

El-Okda, M.K. (1979). Land snails of economic importance at Alexandria region with some notes on the morphological features classification, economic damage $\&$ population on ornamental plants. Agricultural Research Review, 57: 125131.

Eshra, E.H. (2013). Survey and distribution of terrestrial snails in fruit orchards and ornamental plants at Alexandria and ELBeheira Governorates, Egypt. Journal of Alexandria Science Exchange, 34(2): 242-248.

Frandsen, F. (1983). Afield guides to freshwater snails in countries of WHOM. Eastern Mediterranean region: 14-21 Denmark.

Gabr, W.M., Youssef, A.S. and Khidr, F.K. (2006). Molluscicidal effect of certain compound against two land snail species, Monacha obstructa and Eobania vermiculata under laboratory and field conditions. Egyptian Journal Agricultural Research, 4: 43-50.

Genena, Marwa A.M. (2003). Studies on the terrestrial gastropods at Dakahlia Governorate. M. Sc. Thesis, Fac. Agric. Mansoura University, pp. 136.

Godan, D. (1983). Pest slugs \& snails Biology \& control. Springer Verlag Berlin Heidelberg, 73-74: 287-293.

Hashem, A.G., Nakhla, J.M., Tadros, A.W. and Korashy, M.A. (1993). Monitoring land snails on sweet orange trees in Behera Governorate. Egyptian Journal of Agricultural Research, 20: 699-707.

Horst, J. (1958). The young specialist looks at land and freshwater molluscs. Burke publishing, Company Limited, pp. 180. 
Ibrahim, A.M., Bishai, H.M. and Khalil, M.T. (1999). Fresh water mollusca of Egypt.Arab Republic of Egypt, Cabinet of Ministers, EEAA. Publication of National Biodiversity Unit., No.10.

Imevore, E.A. and Ajayi, S.S. (1993). Food preference of the African giant snail, Archachatina marginata in captivity. African Journal of Ecology, 31 (3): 265-267.

Ismail, Sh. A.A., El-Massry, S.A.A., Khattab, M.M. and Hassan, A. Sh. (2003). Daily activity and damage caused by Eobania vermiculata Müller (Gastropoda) in citrus orchards. Egyptian Journal of Agricultural Research, 18: 1-6.

Kassab, A. and Daoud, H. (1964). Notes on the biology \& control of land snail of economic importance in the U.A.R. Journal of Agricultural Research Review, Cairo, 42: 66-98.

Metwally, A.M., Zedan, H.A., El-Saeid, A.B. and El-Akra, T.M.M. (2002). Ecological studies on certain land snails in Monofia \& Gharbia Governorate. Proceedings of $2^{\text {nd }}$ International Conference, Plant Protection Research Institute, Cairo, Egypt: 65-79.

Neubert, E. (1998). Annotated checklist of the terrestrial and freshwater molluscs of the Arabian Peninsula with descriptions of new species. Fauna of Arabia, 17: 333-461.

Pilsbry, H.A. (1948). Land mollusca of North America (North of Mexico), Vol. II part2 Philadelphia: pp. 1130.

Ramzy, R.R. (2009). Biological and ecological studies on land snails at Assiut, Egypt. M. Sc. Thesis, Faculty of Science, Assiut University, Egypt, pp.164.

Sallam A.A.A., El-Massry, S.A. and Nasr, I.N. (2009). Chemical analysis of mucus from certain land snails under Egyptian conditions. Archives of Phytopathology and Plant Protection 42: 874-881.

Shoieb, M.A. (2008). Occurrence and distribution of terrestrial mollusks in Suez canal Governorates and south of Sinai. Egyptian Journal of Agricultural Research, 86: 989- 994.

Smith, B.J. and Kershaw, R.C. (1979). Field guide to the non-marine mollusca of south eastern Australia. Canberra: Australian National University, pp. 283.

Yildirim, M.Z. (2004). Edible snails (terrestrial) of Turkey. Turkish Journal of Zoology, 28: 329-335. 